\author{
Kamila Musial \\ Instytut Zootechniki Państwowy Instytut Badawczy, Zakład Systemów i Środowiska \\ Produkcji
}

Wiestaw Musial

Uniwersytet Rolniczy w Krakowie, Instytut Ekonomiczno-Spoleczny, Zaklad

Ekonomiki i Organizacji Rolnictwa

\title{
Mimikra jako przyklad decepcji w przyrodzie a przejawy oszustwa w ekonomii - wybrane problemy
}

\section{MIMICRY AS AN EXAMPLE OF DECEPTION IN NATURE AND EXPRESSIONS OF FRAUD IN ECONOMY}

\begin{abstract}
W opracowaniu podjęto próbę poszukiwania $i$ objaśnienia analogii pomiędzy uniwersalizmem zjawiska decepcji $w$ przyrodzie $i$ oszustwa $w$ sferze ekonomii. W obydwu obszarach analizy, zjawisko to najczéściej przyjmuje formę mimikry obronnej lub agresywnej. Do wykształcenia złożonych form oszukiwania, czy zwodzenia $w$ świecie zwierzat doprowadziło rozpowszechnienie modelu drapieżca-ofiara, który poprzez maskowanie się lub udawanie kogoś innego, miat zapewnić ochrone przed atakiem lub taki atak ułatwić. W ekonomii można natomiast spotkać postawy przybierajace postać mimikry, a więc analogicznego do przyrody kreowania się na kogoś innego, poprzez oszukańcze strategie stosowane przez różnorodnych wyzyskiwaczy, żerujacych na naiwności stereotypach $i$ automatyzmach ludzkich reakcji. Najczęściej sq one spotykane $w$ sferze marketingu, przybierajac bardzo profesjonalne $i$ wyrafinowane formy postaw marketerów i podmiotów przez nich reprezentowanych. Można tam dostrzec pewien symetryzm i analogie postępowań w zakresie odnoszenia indywidualnych korzyści kosztem innych.
\end{abstract}

Słowa kluczowe: mimikra, przyroda ożywiona, oszustwo, ekonomia

Wstęp

Różnorodne organizmy, takie jak zwierzęta, rośliny, a nawet bakterie są w stanie skutecznie wprowadzać w błąd inne formy żywe, nie wyłączając człowieka. Decepcja w naturze jest zjawiskiem ubikwistycznym, co według terminologii przyrodniczej oznacza, że może występować w każdym dostępnym środowisku, ,wszędobylskim”. Wyraża się ona w ukształtowanym na drodze ewolucji konkurowaniu pomiędzy sobą osobników różnych gatunków o zastane zasoby środowiska. Także człowiek stanowiący część przyrody, z powodzeniem rozwinął taką umiejętność. Decepcja, czy też oszustwem w ujęciu ekologicznym nazywamy taki typ oddziaływań pomiędzy podmiotami, a zatem osobnikami wchodzącymi w interakcje, który jest korzystny dla sprawcy danego aktu, natomiast szkodliwy dla jego odbiorcy. Zwykle wymaga on wystapienia trzech podstawowych elementów: sygnału niosącego fałszywe informacje, nadawcy takiego sygnału czerpiącego korzyść z zaistniałej interakcji oraz odbiorcy na ogół ponoszącego straty. Przyroda uprawia sztukę zwodzenia na różne sposoby i obfituje w 
„przebierańców” starających się wprowadzić w błąd wszystkie możliwe zmysły, przez co wiele takich działań wciąż jeszcze czeka na rozszyfrowanie i zrozumienie. W naukach przyrodniczych wiedza dotycząca decepcji oparta jest głównie o znajomość społecznych zachowań zwierząt oraz mechanizmów ich ewolucji, co umożliwia wyjaśnianie szeregu zjawisk obserwowanych w ich życiu, w tym szeroko rozpatrywanej mimikry. Jest ona swoistą mistyfikacją, której celem jest zapewnienie lepszego dostosowania się organizmów do stale zmieniających się warunków środowiska $[12,13$, $19,23]$.

Według Oczak [27], w zakresie postaw ludzkich decepcja jest konstruktem szerokim, najczęściej definiowanym przez badaczy jako celowe niepełne lub błędne informowanie strony biorącej udział $w$ interakcji. Z kolei Pittenger [30], jest zdania że refleksja wokół problematyki „decepcji” powinna dotyczyć m.in. znaczenia nieprawdziwej informacji zwrotnej oraz rodzaju informacji, które zostały zatajone, co znajduje odzwierciedlenie także w ujęciu ekologicznym. Oznaczać ona może także celowe zatajanie niektórych informacji, które mają szkodliwe następstwa indywidualne lub społeczne, w tym także mieszczące się w sferze ekonomii. Człowiek jest organizmem zaliczanym do królestwa zwierząt, który wykazuje wybitne zdolności do uczenia się, przewyższając pod tym względem wszystkie pozostałe ssaki. Wynika to z wykształcenia niezwykle przydatnej umiejętności, która polega na szybkim analizowaniu i ocenie interakcji z innymi osobnikami, co także istotnie rozszerzyło sposoby różnych form manipulacji i decepcji. Być może także uważna obserwacja świata zwierząt, niegdyś m.in. w celach myśliwskich pozwoliła ludziom odnaleźć analogie do stosowania strategii oszustwa.

Ponadto na drodze swej ewolucji człowiek skutecznie nauczył się poszukiwać społecznej akceptacji dla takich aktów nieuczciwości, które na większą lub mniejszą skalę towarzyszyły ludzkości od zarania dziejów, w tym również niewątpliwie wywarły wpływ na rozwój cywilizacji. Także obecnie niemal powszechnym zjawiskiem w społeczeństwie ludzkim jest oszukiwanie i bycie oszukiwanym na różnych poziomach życia. Jest to uwarunkowane możliwością odniesienia korzyści, zwłaszcza w sytuacjach, gdy od umiejętności zwodzenia może zależeć przetrwanie lub zwiększenie dostosowania jednostki, wyrażające się chociażby $\mathrm{w}$ bogaceniu się i uzyskiwaniu przewagi nad innymi. Zatem oszustwo jest obok altruizmu jedną z dwóch podstawowych postaw społecznych, o wręcz fundamentalnym znaczeniu przystosowawczym. Dlatego też zrozumienie, a następnie manipulowanie takimi kwestiami miało istotny wpływ dla rozwoju naszego gatunku. Na takiej podstawie można wysunąc tezę, że przyroda może być świetną inspiracją dla badania metod, czy strategii decepcji, czy też różnych form oszustwa znanych z teorii i praktyki nauk ekonomicznych [24, 25].

Odniesienia do decepcji widoczne są $\mathrm{w}$ różnych dyscyplinach naukowych, a problem ten jest rozpatrywany zarówno ogólnie, np. w filozofii Kanta, jak i bardziej szczegółowo przez takie dziedziny wiedzy jak etyka, psychologia i socjologia. Istnieją tam wyraźne nawiązania zarówno do samej istoty „oszustwa” oraz jego przejawów, jak też kulturowych elementów „zaufania” społecznego [39, 40]. Według Wilsona [47], badanie różnych postaw społecznych w obrębie wszystkich organizmów żywych, w tym także człowieka, sprowadzane jest do jednolitej zbiorowości poddawanej analizie i ocenie. W teorii tej, człowiek traktowany jest jako kolejny gatunek zwierząt, którego rodzaje postępowania bardziej przypisywane są mechanizmom dziedziczenia, niż 
efektom oddziaływania kultury na jednostkę. Cechy natury ludzkiej zdefiniowane zostały podobnie przez M. Keynsa, który zastosował określenie „Zwierzęcy instynkt”, wskazujące na mocne osadzenie człowieka w zwierzęcej naturze, jako pozostałości po naszej ewolucyjnej przeszłości, przy założeniu że „dzikość nas nie opuściła”. Mieszczą się tu zarówno nieprzewidywalne ludzkie popędy jak i nieraz z pozoru nieracjonalne działania [34].

Na poziomie rozważań ekonomicznych termin oszustwo określa wiele pojęć, są to m.in. akty nieuczciwości jednostek wchodzących $\mathrm{w}$ interakcje ekonomiczne, w tym nieuczciwa konkurencja wynikająca np. z porozumienia pomiędzy stronami, a zatem ze zmowy [9]. Z kolei w nowszym spojrzeniu na zjawisko decepcji, rozpatrywanym przez Akerlof'a i Shillera [1], jego mechanizmy i skutki oceniane sa poprzez jej wpływ na życie gospodarcze, społeczne oraz polityczne. Dla wyjaśnienia tego fenomenu, autorzy stosują aparaturę pojęciową przynależną do ekonomii behawioralnej i psychologii społecznej. Ich zdaniem w procesie badawczym nad oszustwem istotne są odniesienia do sfery marketingu, w tym swoiste narracje „wszczepiane ludziom przez marketerów, specjalistów od reklamy, czy różnych propagandystów".

Celem opracowania było poszukiwanie analogii pomiędzy zjawiskiem mimikry, jako strategii zapewniającej lepsze dostosowanie do środowiska i w efekcie przeżycie różnych gatunków zwierząt, a wybranymi aspektami oszustwa w sferze ekonomii. Zjawisko to zostało przełożone na środowisko ekonomiczne ukształtowane przez człowieka, funkcjonującego w społeczeństwie, w tym w systemach gospodarczych, czy instytucjach opisywanych poprzez nauki ekonomiczne. Zachowania takie wykazują wielopostaciowy charakter oraz wielkość i różnorodność uczestniczących w nich podmiotów i stron. W opracowaniu analogie ze świata przyrody, w postaci strategii stosowanych przez zwierzęta, odnoszono do nieuczciwych postaw biznesowych, w tym stricte ekonomicznych i marketingowych.

\section{Zakres pracy i metodyka}

W opracowaniu o charakterze przeglądowym analizowano wybrane aspekty uniwersalizmu zjawiska oszustwa, czy też decepcji, które odnosi się zarówno do zachowań zwierząt, jak i do postaw ludzkich. Poprzez oszustwo rozumie się świadome wprowadzenie w błąd uczestnika takiej interakcji, w celu czerpania korzyści i realizacji własnych egoistycznych zamiarów, co często wiąże się ze stratą dla odbiorcy takiego aktu, jest zatem zachowaniem podstępnym, kłamliwym [18]. Mimikra to przystosowanie ochronne występujące $u$ różnych zwierząt, polegające na upodabnianiu się zwierząt bezbronnych do zwierząt zdolnych do obrony, np. jadowitych, lub upodobnianiu się do siebie różnych gatunków zwierząt zdolnych do obrony, poprzez przybranie ich kształtu, barwy, czy nietypowego zachowania. Jest zatem swoistą formą oszukiwania potencjalnego przeciwnika żyjącego, w tym samym środowisku. Taka decepcja $\mathrm{w}$ naturze jest szczególnie częsta $\mathrm{w}$ świecie zwierząt, gdzie rozpatruje się ją na dwóch podstawowych poziomach, jako mimikrę obronną, której celem jest uniknięcie drapieżcy oraz mimikrę agresywną, polegającą na maskowaniu się celem łatwiejszego pochwycenia ofiary. Zalicza się tu także zjawisko mimetyzmu, tj. umiejętności maskowania się osobników, pełniącego $\mathrm{w}$ istocie te same funkcje co mimikra $[28,42$, 45]. W takim procesie zawsze uczestniczą trzy nieredukowalne przedmioty: naśladowca, 
model oraz tzw. operator. Naśladowca tworzy zespół cech, upodobniających go do określonych elementów otoczenia, a zatem do modelu. Ma to utrudnić innej formie żywej, tj. operatorowi - potencjalnemu agresorowi prawidłowe rozpoznanie naśladowcy, a zatem ma go wprowadzić w błąd. $\mathrm{W}$ tym procesie naśladowca, poprzez określone formy zachowania lub budowanie upodobnień strukturalnych, dąży do zdezorientowania, a więc wprowadzenia w błąd operatora - agresora. Istotne jest także, że wybór modelu nie jest przypadkowy, ale wyraźnie skorelowany z biologią operatora $[6,12,32,43,48]$

Oszustwo w sferze ekonomii ma wiele postaci i bogactwo treści. Różne mogą być także podmioty uczestniczące $\mathrm{w}$ takim procesie i to zarówno po stronie oszukującego jak też i oszukiwanego. Mogą to być podmioty gospodarcze oszukujące się wzajemnie poprzez stosowanie różnych form decepcji, np. korporacje, banki czy firmy, jak i osoby fizyczne w sposób nieuczciwy „,grające” o różnorakie korzyści, w tym np. najrozmaitsze formy oszukańczych postaw stosowanych w sferze marketingu. W opracowaniu przyjęto symetrycznie opis wybranych rodzajów podstępnych działań i mistyfikacji wykorzystywanych przez różne zwierzęta, jak również pokrętnych postaw człowieka, uwidaczniających się w sferze ekonomii. Symetryzm prowadzonych analiz oznacza, że do mimikry obronnej i agresywnej, które $\mathrm{w}$ przyrodzie są strategiami zwodzenia przeciwnika, odniesiono pojęcie oszustwa w ekonomii, na przykładzie szczególnych poczynań i relacji firm oraz konsumentów. Poszukiwano analogii w ich zachowaniu, zwłaszcza w budowie dominacji na rynku, w tym poprzez różnorodne działania marketingowe. Metoda analogii posłużyła zatem jako sposób poznawania i analizy obserwowanych zjawisk, w oparciu o założenie, że nauki przyrodnicze mieszcząc w sobie wiele dziedzin poznawania, są starsze i bardziej zaawansowane metodycznie w zakresie opisu procesów i struktur niż nauki ekonomiczne [23, 26].

Ograniczanie analiz do decepcji obronnej $\mathrm{i}$ agresywnej wynika $\mathrm{z}$ niewielkich rozmiarów opracowania, z zachowaniem świadomości istnienia rozległego obszaru obserwacji i opisu określonych postaw. Pomimo, że według Stachaka [35] analogia należy do niepewnych metod rozumowania, to jednak sposób ten może być twórczy i wnosić do badań wątek interdyscyplinarności oraz uniwersalności wyrazu i ocen. Analogia oparta jest tutaj o poszukiwanie podobnych relacji pomiędzy podmiotami analiz lub stosowanie tych samych schematów w zakresie postaw $\mathrm{i}$ ich spodziewanych następstw. O ile w świecie przyrody opisy zachowań zwierząt odnoszono do konkretnych rodzajów lub nawet gatunków, to jednak w sferze ekonomii podawane przykłady, ze zrozumiałych względów (zwłaszcza prawnych) potraktowano anonimowo.

\section{Poszukiwanie symetryzmu dla zjawiska decepcji w przyrodzie oraz oszustwa w ekonomii}

W świecie ożywionym do uniwersalizmu zjawiska mimikry doprowadziło rozpowszechnienie modelu drapieżca-ofiara. Objawia się on tym, że obecność drapieżników wpływa na wykształcanie różnych przystosowań u organizmów będących ich potencjalnymi ofiarami. Jednym z przykładów takiej decepcji, szeroko określanej jako mimikra obronna, jest wykorzystanie strategii polegającej na byciu nieprzydatnym dla drapieżnika, poprzez postawienie na bycie niejadalnym. Można to uzyskać dzięki wykształceniu obrony chemicznej w postaci jadów i trucizn, które są niegroźne dla 
produkującego je organizmu, a śmiertelne dla drapieżnika. Takie zjawisko obserwowane jest m.in. wśród niezwykle jaskrawo ubarwionych, trujących żab południowoamerykańskich oraz pewnych gatunków ptaków z rodzaju Pitohui, występujących w lasach równikowych Nowej Gwinei. Istotnym elementem jest tu postawienie na wykształcenie cech sygnalizujących niejadalność potencjalnej ofiary, poprzez charakterystyczny wygląd i zapach, określane jako cechy aposematyczne.

Pomimo, że jak podają różni badacze, drapieżcy szybko uczą się rozpoznawać i unikać organizmów o takich właściwościach, proces ten przy okazji doprowadził do wykształcenia innej, interesującej adaptacji nazywanej mimikrq müllerowska. Polega ona na upodabnianiu się do siebie osobników różnych niebezpiecznych lub niesmacznych gatunków, zamieszkujących ten sam obszar, co ma zwiększyć szansę tych zwierząt na przeżycie w obliczu ewentualnego ataku drapieżcy [5, 45]. Innym przystosowaniem, a zarazem wyrafinowanym oszustwem jest strategia nazywana mimikra batezjańskq, występująca wówczas, gdy bezbronne gatunki udają formy posiadające mechanizmy obronne. Ta forma mimikry jest szczególnie często spotykana u różnych owadów, zwłaszcza wśród motyli. Jej skuteczność polega na tym, że gdy dwa gatunki są podobne, drapieżnik będzie je ze sobą mylił i zanim nauczy się je wreszcie odróżniać, zginie mniejszy procent osobników obu gatunków. Ponieważ obydwie strony korzystają na tym podobieństwie, nie ma jasnego podziału na oryginał i naśladowcę, choć jest on wyraźniejszy, gdy jeden z gatunków występuje rzadziej od drugiego, niż gdy mają zbliżoną liczebność $[21,22,45,46]$.

Odrębny rodzaj mimikry obronnej stanowi zjawisko mimetyzmu, polegające na zdolności do maskującego upodabniania się wyglądem do otoczenia, dzięki czemu zwierzę zyskuje dodatkową ochronę przed naturalnymi wrogami. Nierzadko stanowi to wizualnie perfekcyjną ułudę. Strategia taka jest niezwykle rozpowszechniona u różnych grup systematycznych, m.in. pośród owadów czy ryb i dotyczy gatunków u których plan budowy ciała podporządkowany jest funkcji ukrycia się przed okiem drapieżnika. Mimetyzm może polegać na upodabnianiu się niektórych gatunków zwierząt kształtem, barwą lub deseniem na powierzchni ciała, do otaczającego środowiska lub do innych organizmów. Daje to szansę na uniknięcie szkodliwych i niebezpiecznych dla nich kontaktów z innymi organizmami, poprzez ,podawanie się za kogoś innego”. Mimetyzm obserwowany jest głównie u owadów, które maja zdolność upodabniania się do elementów otoczenia barwą oraz kształtem. Przykładem jest zjawisko homochromii, polegające na przybieraniu przez zwierzę barwy podłoża, co może zapewnić bezpieczne schronienie przed drapieżnikami. Tego typu rozwiązania stosują np. gąsienice ćmy kapturnicy byliczanki, które ze względu na barwny wzór na ciele bardzo trudno odróżnić od pędów rośliny na której żerują, a zatem od bylicy. Owady wprowadzają w błąd napastnika w jeszcze inny sposób, niektóre motyle posiadają wzory barwne na ciele, imitujące głowę lub oczy. Skrajnym przykładem jest tropikalny motyl z Trynidadu i Tobago, Dynastor darius darius, który po przeistoczeniu się w poczwarkę zaczyna przypominać wyglądem węża. Ogólnie pojęcie mimetyzmu należy rozumieć w szerokim zakresie, gdyż obejmuje nie tylko przystosowanie ochronne potencjalnych ofiar, lecz również maskowanie się drapieżników czatujących na potencjalne zdobycze $[28,42$, 45].

Odwrotną strategię stosują zwierzęta używające mimikry agresywnej, uznawanej za majstersztyk przewrotności, która także jest bardzo rozpowszechniona w świecie 
organizmów żywych. Dla nich kamuflaż i decepcja służą nie uniknięciu drapieżcy, lecz skuteczniejszemu schwytaniu ofiary. W tej formie decepcji drapieżnicy używają różnych sygnałów podobnych do niegroźnych modeli, dzięki czemu nie zostają rozpoznani przez ofiarę. Niekiedy drapieżca upodobnia się pod określonym względem do swej ofiary, co można obserwować u samicy jednego z drapieżnych świetlików z Ameryki Północnej z rodzaju Photuris. Wabią one, a następnie pożerają męskie osobniki innych rodzajów świetlików, np. z rodzaju Photinus. Jest to możliwe ponieważ gody u świetlików odbywają się nocą i warunki zewnętrzne sprawiają, że poszczególne gatunki nie mogą rozpoznać się na podstawie cech morfologicznych, a jedynie poprzez sygnały świetlne charakterystyczne dla danego rodzaju. Jest to oczywiście świetną okazją do zastosowania jakiegoś mechanizmu decepcji. Samice Photuris wykonują świetlne wzory imitujące sygnały godowe samic robaczków świętojańskich należących do tego drugiego rodzaju, przez co są w stanie oszukać i przyciagnąć do siebie odpowiednie samce, które padają ich łupem. Samice te rozpoznają i posługują się sygnałami świetlnymi co najmniej dwunastu gatunków innych świetlików, przez co znaczna część ich męskich osobników jest przez nie pożerana. Wydaje się, że ich świetlne, bioluminscencyjne sygnały wyewoluowały niezależnie i w końcu zaadoptowały się do ofiary, należącej do innego rodzaju. Zatem u świetlików forma niebezpieczna, upodabnia się do tego, co dla operatora wydaje się bezpieczne, a więc do samicy jego gatunku. Upodabnianie się naśladowców do określonego modelu ponad wszelką wattpliwość służy wprowadzaniu operatora w błąd $[4,11,12,15,16,32,36,44]$.

Mistrzem decepcji jest także żyjący w Ameryce Północnej pająk z rodzaju Mastophora. Znany jest dzięki stosowanej przez samice unikatowej techniki łapania ofiar, polegającej na wytwarzaniu cienkiej jedwabnej nici, wyposażonej w bardzo klejące zakończenie oraz wykorzystywaniu strategii określanej jako chemiczna mimikra agresywna. Takie pajęcze ,femme fatale" specjalizują się w jedzeniu ciem płci męskiej, gdy te się zbliżają pająk używa jednego odnóża, aby wirować nić wokół ofiary, aż ta zostaje oblepiona, a następnie przyciaga ćmę i pożera. W tym przypadku sygnał jest chemiczny, ponieważ pająki uwalniają mieszanki związków, które pasują składem do feromonów wytwarzanych w trakcie okresu godowego przez samice tych ciem. Może tworzyć łańcuch powiązań: ćma, agresywny pająk-mimik i fałszywe feromony. Co więcej, dokładniejsze badanie tego modelu decepcji ujawniło, że istnieje ponad 60 gatunków takich pająków, w obrębie trzech rodzajów, a wiele potencjalnych gatunków motyli nocnych służy jako możliwa zdobycz. Pojedyncza samica takiego pajaka w ciagu jednej nocy może przyciagnąć męskie ćmy należące do więcej niż jednego gatunku [8, $10,37,49]$.

Innym przykładem mimikry agresywnej jest fortel, jaki stosują zamieszkujące pustynie USA chrząszcze z rodzaju oleic. Pośród traw będących typowym miejscem żerowania pszczół, samice tych chrząszczy składają jaja z których równocześnie wylęgają się larwy. Tysiące larw zbijają się w jajowaty kłąb, tworząc coś w rodzaju jednego organizmu, przez co z daleka na źdźble trawy prezentują się jako pszczoła samotnica. Ponadto taka kolonia larw zaczyna rozsiewać substancję do złudzenia przypominająca feromony wydzielane przez samice pszczół, co służy przyciągnięciu trutni. Kiedy zjawi się samiec, larwy rzucają się na niego i uczepiają odwłoka, zanim ten spostrzeże się, że został oszukany, wiezie już na sobie gromade ,pasażerów na gapę”. W trakcie zbliżenia z prawdziwą samicą przekaże jej niejako przy okazji larwy oleic, które 
dzięki temu zdobędą dostęp do obficie zaopatrzonego w pokarm gniazda prawdziwej pszczoły samotnicy. Tam będą konsumować nektar, pyłek, a przede wszystkim jaja „gospodyni”. Strategia gdzie wiele organizmów upodobnia się do pojedynczego przedstawiciela innego gatunku, nazywana jest mimikra grupowa [33].

Przykłady mimikry u bezkręgowców mogą być mnożone bez końca, a grupa szczególnie obfitująca we wszelakie rodzaje stosowanych zabiegów decepcji są owady. Wśród kręgowców rzadziej można napotkać tego typu strategie, co wynika m.in. z niewielkiej liczby gatunków zwierząt kręgowych w stosunku do tej drugiej grupy, niemniej różne strategie oszukiwania przeciwnika stosowane są np. przez ptaki czy płazy. Z punktu widzenia człowieka istotne $\mathrm{w}$ tej kwestii wydaje się być przede wszystkim niedopasowanie między wizualnym światem ludzi, a światami: chemosensorycznym, słuchowym i dotykowym większości innych kręgowców i bezkręgowców. Stąd skutecznie ukrywały one przed nami wiele przejawów mimikry, a człowiek długo nie był w stanie wychwycić takich strategii. Jednak systematyczne badania informacji, które zwierzęta przekazują za pomocą tych metod sensorycznych, prawdopodobnie ujawnią szereg dodatkowych przykładów mimikry [31].

Mimikra oraz mimetyzm bardzo często występują także w sferze ekonomii, tj. w odniesieniu do gospodarstw domowych, poszczególnych konsumentów, czy też firm. W tym wydaniu jest to specyficzny sposób zachowania adaptacyjnego, kiedy określone podmioty reprezentowane m.in. przez konkretne jednostki lub ich liderów, świadomie zniekształcają przyjęte systemy wartości normatywnych, tworząc zarazem nowe, zamaskowane role społeczne, czy funkcje ekonomiczne. Biorąc pod uwagę, że społeczność ludzka ma w mierzalnym czasie źródło swego pochodzenia w świecie zwierząt, a czas ten z punktu widzenia trwania ewolucji biologicznej jest bardzo krótki, można założyć, że wiele cech zwierzęcych zostało przeniesionych bezpośrednio do populacji ludzkich, a dalej do sfery ekonomii. Zdolność do takiej mimikry jest genetycznie zaprogramowana w mózgu człowieka, ale też formuje się pod wpływem danej przestrzeni społecznej i czasowej, w której konkretna jednostka socjalizuje się i prowadzi działalność ekonomiczną i życiową. Oznacza to, że do „mimikryzacji”, a zatem naśladownictwa przyczyniają się zakodowane w nas cechy nie tylko społeczne, ale i zwierzęce, nabywane w trakcie rozwoju osobniczego. Stąd można odnaleźć jakiś sens w odwoływaniu się do oszustwa, będącego wynikiem przebiegłości, jako elementu zapewniającego łatwiejsze dostosowanie do przestrzeni społeczno-czasowej [17].

Analizując fenomen oszustwa, będącego strategią wykorzystywaną szeroko w sferze ekonomii, powstaje kwestia ukazania pokrętnych lub nieszczerych postaw różnych podmiotów, których celem jest osiagnięcie wymiernych korzyści w jakiejś przestrzeni, w sposób najłatwiejszy, najtańszy oraz najszybszy. Egoizm przedsiębiorstw lub wprost przedsiębiorców, jeśli poddamy ich personifikacji oraz chęć zysku i bogacenia się na drodze nieuczciwej konkurencji, od wieków były ważnymi lub wręcz głównymi siłami napędzającymi światową gospodarkę. Dlatego też jednostki potrafiące efektywnie lokować zarówno swój kapitał, jak i życiową energię, odnosiły sukces skuteczniej od innych [2, 3, 41]. Dzięki temu także efektywnie rosła ich siła i konkurencyjność, która według Milczarek-Andrzejewskiej [20], definiowana jest jako: „,prawdopodobieństwo, że jeden z podmiotów w sieci związków społecznych zrealizuje swoją wolę, pomimo oporu innych". Wiąże nas to wyraźnie ze światem zwierząt, a o życiu w społeczeństwie mówi się czasem jako o „ludzkiej dżungli”, gdzie można 
napotkać strategie mimikry pod postaciami najróżniejszych wyzyskiwaczy, żerujących na ludzkich automatyzmach, stereotypach czy kulturze.

Różnego typu oszustów, manipulatorów czy wyzyskiwaczy stosunkowo najłatwiej odnaleźć można w sferach działalności o charakterze ekonomicznym, zwłaszcza w obszarze marketingu. Ta rozbudowana dziedzina nauki i praktyki gospodarczej wypracowała olbrzymi zasób wiedzy naukowej i potocznej odnośnie kreowania produkcji $\mathrm{i}$ sterowania rynkiem oraz produktami, m.in. poprzez wywołanie $\mathrm{w}$ konsumentach silnych mechanizmów zainteresowania i chęci posiadania. W tym zakresie można odnaleźć bardzo wiele przykładów, zarówno w literaturze przedmiotu jak też poprzez doświadczenia osobiste. Często akcje promocyjne w sklepach poprzedzone są najpierw podwyżkami cen, aby później móc je obniżyć i w podobnej cenie sprzedać towar jako tani, a więc stosowane jest oszustwo poprzez „kreowanie” tzw. okazji [29]. W takiej metodzie sprzedaży towarów, można by upatrzeć się pewnych analogii do wzorców opisujących np. strategię mimikry batezjańskiej, a zatem pomimo że brak jest danej cechy, osobniki lub podmioty udają, że są w nią zaopatrzone.

Niezwykle często spotykane są także różne sposoby podstępnego ataku na klienta, przybierające niejednokrotnie wyrafinowane postacie manipulacji psychologicznej, których celem jest „złowienie” nabywcy. Wspomniana strategia marketingowa może się także odnosić do metody określanej jako ,fishing”, polegającej właśnie na „złowieniu” amatora, którą w przyrodzie można by odnieść np. do zarzucania jedwabnej, z pozoru niewinnej, lecz bardzo lepkiej nici samicy pająka z rodzaju Mastophora. Podobnie istota ,fishingu" sprowadza się do generowania sytuacji niekorzystnych dla biorcy aktu, z wierzchu wyglądających na niegroźne, a wręcz korzystne. Polegają one na poszukiwaniu i nakłanianiu ludzi do podejmowania decyzji niezgodnych z ich własnym interesem, lecz korzystnych dla strony manipulującej, wykorzystującej ich naiwność, łatwowierność lub brak wiedzy. Sytuację tą można także określić jako tzw. „niewinne oszustwo”, które w sferze ekonomii wskazuje na trudności w jego dostrzeganiu, instytucjonalizację, ale także jego uznanie i legalizację, co zwłaszcza odbywa się w sferze dużego biznesu korporacyjnego [7]. Wspomniane łowienie nabywcy, to zwykle zespół takich działań jak: manipulowanie, kombinacje i stosowanie „sztuczek”, co może mieć miejsce także w warunkach równowagi rynkowej. Jest tu zarówno „rybka” - ofiara, jak i przynęta (wabik), czyli przedmiot oferowany na sprzedaż. I nie chodzi o to, że w gospodarce rynkowej $\mathrm{w}$ sferze obrotu działają wyłącznie źli ludzie, lecz jest to cecha naszego systemu ekonomicznego. Kupujemy zatem rzeczy niekoniecznie potrzebne i zadłużamy się $\mathrm{w}$ bankach korzystając $\mathrm{z}$ bardzo dobrze przygotowanych ofert kredytowych „najlepszych” kart płatniczych, zbyt łatwo akceptując wyrafinowaną narrację marketingową. Jesteśmy często „rybkami”, które łatwo złowić, a potem wręcz je „hodować”, tak aby rosła ich wartość i jak najdłużej mogły przynosić korzyści, aby ciagle kupowały i odnawiały to dobro, które często może być po prostu zbędne.

Inny przykład stanowią strategie marketingowe, często stosowane w różnych supermarketach, polegające na rozdawaniu darmowych próbek towarów. W efekcie potencjalny klient czuje się $\mathrm{w}$ jakimś stopniu zobowiązany do zakupu reklamowanego produktu, jedynie z racji tego że nie wypada „być niewdzięcznikiem”. Przez to wzrasta prawdopodobieństwo, że zakupi on towar, którego wcale nie uwzględniała jego wcześniejsza lista zakupów. Można tutaj odnieść dobrze funkcjonującą w przyrodzie i opisaną w socjobiologii metodę określaną jako zasada wzajemności [47]. Efektywność 
jej działania w przypadku relacji międzyludzkich wiąże się z kulturowo ukształtowaną wolą odwdzięczenia się za otrzymane dobro, które tu jednak jest jedynie sprytnie zastawioną pułapką [1]. Nie jest ona w rzeczywistości niczym innym jak tylko rodzajem miтеtyzmu, według wzoru że nasze prawdziwe intencje są niewidoczne i maskowane, zgodnie ze zjawiskiem homochromii znanym ze świata zwierząt. Strategia ta może także przybierać formę typową dla mimikry agresywnej, tym bardziej podstępną, że mimik podaje się za altruistę i sprytnie zastawia pułapkę, aby zrealizować swe egoistyczne cele, a więc osiagnąc jak największy zysk.

Podobnie jak robią to niektóre gatunki zwierząt, także różni specjaliści zajmujący się np. reklama, zwiększają sprzedaż stosując wyrafinowane sposoby manipulacji marketingowej ,imitujące określone sygnały” dla potencjalnych klientów, a więc stosują mechanizm analogiczny do mimikry i mimetyzmu. Korzystając $z$ wiedzy psychologicznej o naturze i rodzajach ludzkich zachowań warunkowanych: wiekiem, wykształceniem, wykonywanym zawodem, czy kulturą środowiska w którym żyją, korzystają oni z szerokiego instrumentarium sposobów na zdobycie klienta. Stosują w tym celu sprawdzone narracje rozbudzające pragnienia posiadania i wyróżniania się. Dotyczyć to może zarówno codziennie kupowanego chleba, „specjalnie dla nas pieczonego", jak też samochodów, mieszkań czy domów. Szczególnie nachalny, moralnie wątpliwy, a nawet naganny jest marketing leków. Ma on długą historię, a stąd i bardzo dużo, świetnie opracowanych metod prowadzenia kampanii marketingowych. Walka toczy się o to aby dany lek, czy też paralek kupowali nie tylko chorzy, ale także osoby zdrowe, rekrutujące się np. z kręgu rodzinnego pacjenta lub jego najbliższego otoczenia. Ponadto taki farmaceutyk powinien także uzyskać refundacje od Państwa, co dodatkowo zwiększy jego dostępność oraz zyski producenta, jak również być promowany przez łatwo dostępne czasopisma. Ponadto według filozofii marketerów dobrze byłoby także aby odstawienie takiego leku okazało się szczególnie nieprzyjemne, co skutecznie wydłuży czas jego zażywania [2].

Oszustwo w ekonomii ma miejsce w tych dziedzinach życia, w których pomysłowość i przebiegłość człowieka może przynieść mu korzystne, a nawet spektakularne efekty. Zwłaszcza w ekonomii Zachodu powszechnie znane są tzw. bankructwa dla zysku, będące także formą mimikry. Stanowią one zwykle wyrafinowane formy kolejno postępujących po sobie działań oszukańczych, np. poprzez: zmowę, kreatywną księgowość, wyprowadzanie pieniędzy poza firmę, tworzenie pozornych problemów kadrowych itp. Udając słabą kondycję, czy „chorobę firmy”, w rzeczywistości prowadzony jest rabunek wielu kontrahentów, dzięki czemu generowane są duże zyski dla danego podmiotu. Jest to niczym innym jak znanym $\mathrm{z}$ natury stosowaniem ubarwienia ostrzegawczego, które ma zniechęcić potencjalnych napastników. Nawiązuje to zatem do wykształcania przez niektóre zwierzęta tzw. cech aposematycznych, wskazujących na daną właściwość osobnika czy podmiotu. Metody takie w odniesieniu do firm stosowane były dość powszechnie i wydaje się, że nadal mogą być stosowane na rynku nieruchomości i firm w USA, szczególnie w okresach recesji gospodarczej [1].

Inny przykład przedstawiają firmy nie radzące sobie na rynku, borykające się z problemami finansowymi lub prawnymi, które jednak przybierają wizerunek liderów w branży. Budują one swój zwodniczy image, analogicznie do strategii stosowanej przez bezbronną poczwarkę wspomnianego motyla z Trynidadu i Tobago, której obroną jest 
udawanie groźnego węża. Podobnie jak w przypadku motyla Dynastor darius darius, strategia ta służy przetrwaniu, jednak w odniesieniu do firm generuje ona także wiele dalszych konsekwencji w postaci: narażania na straty finansowe dostawców, podwykonawców i odbiorców finalnych. Praktyki takie, często spotykane są w budownictwie, zwłaszcza wśród deweloperów. Takie małe firmy broniąc się, aby nadal móc pozostać na rynku, stosują również znaną wśród zwierząt mimikrę müllerowska, a więc upodabniają się do innych wedle zasady, że w większej grupie jednostka jest stosunkowo słabo widoczna. Odbywa się to poprzez dołączanie do sieci franczyzowych, dzięki czemu mały sklep, piekarnia, czy fryzjer może stać się częścią dużego, szanowanego i mocno reklamowanego biznesu. Dzięki temu zyskuje uznanie, zajmuje nową i lepszą pozycję na rynku, choć właściciel jest nadal relatywnie biedny, a biznes nisko opłacalny. Podmioty takie dzięki zastosowaniu strategii oszustwa mogą przetrwać, poprzez uzyskanie wsparcia lidera a klient nie wie, że ta „potęga” jego partnera rynkowego to jedynie pozory i swoista mistyfikacja. Innym przykładem mogą być obwoźni sprzedawcy, zwłaszcza prowadzący sprzedaż na targowiskach $\mathrm{w}$ formie jarmarcznej, którzy z reguły występują w większych grupach. Na targach, np. sobotnich, organizowanych w małych miasteczkach wystawiają i sprzedają oni podobne do innych lub tożsame towary. Wśród nich zdarzają są jednak tacy handlowcy, którzy sprzedają towar niskiej jakości lub wręcz wadliwy. Upodabniają się jednak do otoczenia stosując strategie mimetyzmu, bądź też wspomnianej mimikry batezjańskiej. Dzięki temu mogą „schować się w tłumie” i chronić, a nawet dalej rozwijać swój biznes.

Częstymi działaniami oszukańczymi $w$ ekonomii są także przejęcia lub zawłaszczenia firm poprzez agresywne i ekspansywne grupy kapitałowe, które przygotowuja, w tym celu wyrafinowane i sprawdzone praktyki biznesowe. Przykładem takich postaw może być kupno małej firmy z danej branży, celem rozpoznania stanu, potencjału i sytuacji rynkowej podobnych firm, a nawet nawiązania kontaktów partnerskich $\mathrm{z}$ ich liderami. W fazie drugiej następuje mniej lub bardziej podstępne ich podkopywanie i niszczenie, czyli „,pożeranie” np. poprzez stosowanie metody dumpingu. Można tutaj zaobserwować pewną analogię do drapieżnych świetlików z rodzaju Photuris, które wysyłają błędne sygnały mające zdezorientować osobniki należące do innego rodzaju, po to aby móc je pożreć. Ten typ oszustwa można zatem odnieść do mimikry agresywnej $\mathrm{w}$ świecie zwierząt. W sferze ekonomii znanych jest wiele metod takiego „łapania ofiar”. Często bankrutujące firmy są tanio kupowane, przy czym ich bankructwem mniej lub bardziej steruje tzw. „łowca”. Następnie dzięki zatrudnieniu zdolnych managerów takie przejęte już firmy są uzdrawiane i wyprowadzane na prosta, a managerowie zaraz po tym jak już osiagną sukces rynkowy są zwalniani, a firmy wyceniane i ponownie sprzedawane. Strategia taka może być stosowana okazjonalnie, sytuacyjnie lub też stanowić stały sposób utrzymania się „biznesmenów”, działających analogicznie jak drapieżnicy w przyrodzie [14].

Kolejny przykład na występowanie takich analogii stanowią praktyki mieszczące się w sferze marketingu terytorialnego, które są wprost zapożyczone od świata zwierzęcego, gdzie małe zwierzęta poprzez swe zachowania udają duże. W zjawisku tym można dostrzec także analogie do tzw. mimikry grupowej, w której wiele drobnych organizmów, będzie upodobniać się do jednego dużego, jak w przypadku dużej liczby larw chrząszczy, udających pojedynczą samicę pszczoły. Zwierzęta poprzez mimikrę udają większe, silniejsze, jak również mogą dostosowywać się barwą i kształtem do 
otoczenia. Sytuację tą można odnieść także np. do niektórych miast, które są mało atrakcyjne dla potencjalnych zwiedzających, ale leżą na szlaku turystycznym. Władze takiego miasta mogą stosować agresywny marketing terytorialny, oparty na promocji oraz nachalnej reklamie, lansując symboliczną „kupę kamieni” jako coś oryginalnego i godnego uwagi [38]. Takie działania podobnie jak wiele innych strategii mimikry, zwodzenia, czy wręcz akceptowanego prawnie oszustwa, oceniane są jednak negatywnie w kategoriach moralnych, przez co mogą być sprawdzalne jedynie na krótką metę.

\section{Podsumowanie}

Oszukiwanie i zwodzenie na drodze mimikry jest bardzo rozpowszechnione pośród różnych gatunków zwierząt. Stąd ważna jest świadomość istnienia możliwości ekstrapolacji pewnych strategii funkcjonujących $\mathrm{w}$ przyrodzie, np. do wybranych mechanizmów działania firm. Znajomość złożoności takich aktów może pomóc w osiągnięciu sukcesu, ale także w ustrzeżeniu się przed nieuczciwymi konkurentami. A zatem człowiek w swoich dążeniach do zwiększenia sukcesu ekonomicznego, np. w postaci dobrze prosperującej firmy, może uczyć się dzięki czerpaniu wiedzy ze strategii stosowanych przez najróżniejsze gatunki zwierząt, pochodzących z różnych cześci świata oraz grup systematycznych. Przypadki takiego zwodzenia mogą być przeniesione na poziom ludzki, zwłaszcza kiedy myślimy o intencjonalnym oszukiwaniu w odniesieniu do sfery marketingu. Pomimo, że zwierzęta działają instynktownie, w niektórych świadomych postawach ludzkich można odnaleźć analogię do ich reakcji. Być może znajomość praw rządzących przyrodą mogłaby dać podstawy dla polepszania mechanizmów działania różnych przedsiębiorstw, co jest obecnie sporym wyzwaniem m.in. dla ekonomistów, ale także psychologów oraz socjologów.

$\mathrm{W}$ analizowanych zjawiskach mimikry i mimetyzmu, stanowiących strategie decepcji w przyrodzie, ale także oszustwa w ekonomii, można dopatrzeć się także pewnych podobieństw w ich podłożu oraz przebiegu. Podobnie jak ludzie wychowujący się w rodzinie, szkole, czy też ujmując szerzej w społeczeństwie, zyskują kod kulturowy warunkujący ich zachowanie $\mathrm{w}$ otoczeniu i w świecie gospodarczym, zwierzęta uczą się od rodziców walki o pokarm i terytorium. W obydwu rozważanych grupach, w wielu formach postaw i zachowań można doszukać się zatem pewnych postaci symetryzmu, czy też analogii. W sferze marketingu wypracowano najróżniejsze, często niezwykle wyrafinowane metody zwodzenia. Niektóre koncepcje marketingowe mogą stosować połączenie kilku strategii znanych ze świata zwierząt, a zatem przyroda może być nieskończoną wręcz inspiracją dla poczynań ekonomicznych, zarówno dla poszukiwania nowych, niestosowanych dotąd metod zwodzenia, jak i możliwości ochrony przed byciem oszukanym. Jednak o ile w świecie zwierząt dla strategii decepcji nie stosuje się odniesień etycznych, to postawy ludzkie $\mathrm{w}$ sferze ekonomii niewatpliwie podlegają takim ocenom. Jest to być może główna determinanta odróżniająca mimikrę w przyrodzie od oszustwa w ekonomii.

\section{Bibliografia}

Akerlof G.A., Shiller R.J. 2017. Złowić frajera. Ekonomia manipulacji i oszustwa. PTE, Warszawa: XII-XV. 
Cameron R., Neal L. 2004. Historia gospodarstwa świata. Wyd. Książka i Wiedza, Warszawa: 104-131.

Cialdini R.B. 2016. Wywieranie wpływu na ludzi. Teoria i praktyka. Wyd. GWP. Sopot: 20-58.

Dawkins R., Krebs J.R. 1978. Animal signals: information or manipulation? [W:] Krebs JR, Davies N.B, editors. Behavioural ecology: an evolutionary approach. Oxford: Blackwell Scientific Publications: 282-309.

Diamond J.M. 1975. Assembly of species communities. [W:] Ecology and evolution of communities, red. J.M. Diamond, M.L. Cody. Cambridge, M.A., Belknap Press.

Gabriel A. J. 2017. Signals, cues and the nature of mimicry. Proc Biol Sci. 284: 1849.

Galbraith J.K. 2004. Gospodarka niewinnego oszustwa. Prawda naszych czasów. Wyd. MT Biznes, Warszawa: 13-75.

Gemeno C., Yeargan K.V., Haynes K.F. 2000. Aggressive chemical mimicry by the bolas spider Mastophora hutchinsoni: identification and quantification of a major prey's sex pheromone components in the spider's volatile emissions. J. Chem. Ecol. 26:1235-1243.

Haffer R. 2002. System zarządzania jakością w budowie przewag konkurencyjnych przedsiębiorstw. Wydawnictwo UMK. Toruń.

Haynes K.F., Gemeno C., Yeargan K.V., Millar J.G., Johnson K.M. 2002. Aggressive chemical mimicry of moth pheromones by a bolas spider: how does this specialist predator attract more than one species of prey? Chemoecology.12: 99-105.

Horn D.J. 1978. Biology of insects. W.B. Saunders Company, Philadelphia, London, Toronto.

Koszteyn J. 2005. Zjawisko mimikry a problem decepcji. Philosophia vitam alere. WSF-P Ignatianum", Wyd. WAM, Kraków: 277-303.

Kośmicki E. 1994. Socjobiologia - nauka o społecznych zachowaniach zwierząt i człowieka. Uwagi na marginesie książki Eckarta Volanda. Przegląd Antropologiczny. 57(1-2): 107-112.

Kubiczek A. 2015. Nierówności Społeczne a Wzrost Gospodarczy. Czasopismo Uniwersytetu Rzeszowskiego. 42(2): 266-280.

Lloyd J. 1975. Aggressive mimicry in Photuris fireflies: signal repertoires by femmes fatales. Science. 187(4175): 452-453.

Lloyd J.E. 1981. Mimicry in the sexual signals of fireflies. Scientific American. 245(1): 110-117.

Lobanova A. 2014. Mimikra społeczna w sferze nauki: treść i formy jej przejawiania się. Zeszyty Naukowe Politechniki Śląskiej. Seria: Organizacja i Zarządzanie. 72: 115-124.

Mały słownik języka polskiego 1997. PWN Warszawa: 584.

Maynard-Smith J., Harper D. 2003. Animal Signals. Oxford Series in Ecology and Evolution.

Milczarek-Andrzejewska D. 2014. Zagadnienia siły w ekonomii - na przykładzie sektora rolnospożywczego w Polsce. IRWIR PAN. Warszawa: 17-43.

Müller F. 1878. Ueber die Vortheile der Mimicry bei Schmetterlingen. Zoologischer Anzeiger. 1: 54-55.

Müller F. 1879. Ituna and Thyridia; a remarkable case of mimicry in butterflies (translated by Meldola, R.). Proclamations of the Entomological Society of London: 20-29.

Musiał K., Musiał W. 2011. Ekstrapolacja hipotezy Czerwonej Królowej z nauk przyrodniczych do ekonomicznych w aspekcie konkurencyjności i postępu. Roczniki Naukowe Stowarzyszenia Ekonomistów Rolnictwa i Agrobiznesu. 13(8): 159-164.

Musiał K., Musiał W. 2016. Konkurencja w naturze a natura konkurencyjności w gospodarce. Roczniki Naukowe Ekonomii Rolnictwa i Rozwoju Obszarów Wiejskich. 103(3): 22-31.

Musiał W., Musiał K. 2012. Altruism in biology regarding disinterested forms of action in economy (selected aspects). Acta Scientarum Polonorum. Seria Oeconomia. 11(2): 45-55.

Nowak S. 2008. Metodologia badań społecznych. PWN Warszawa.

Oczak M. 2007. O możliwości stosowania procedury „decepcyjnej” z punktu widzenia ogólnych zasad etycznych. Przegląd Psychologiczny. 50(3): 273-286.

Olszowska M. 2011. Kolory przyrody. Wszechświat. 112(4-6): 148-153.

Piercy N. 2003. Marketing. Strategiczna reorientacja firmy. Wyd. Felberg SJA. Warszawa: 23-78. 
Pittenger, D. J. 2002. Deception in research: Distinctions and solutions from the perspective of utilitarianism. Ethic and Behavior. 12(2): 117-142

Pough H.F. 1988. Mimicry of vertebrates: are the rules different? The American Naturalist. 131.

Russell E.S.1938. The behaviour of animals. An introduction to its study. Edward Arnold \& Co., London.

Saul-Gershenz L., Millar J. 2006. Phoretic nest parasites use sexual deception to obtain transport to their host's nest. Proceedings of the National Academy of Sciences. 103: 38.

Sedlacek T. 2011. Ekonomia dobra i zła. W poszukiwaniu istoty ekonomii. Od Gilgamesza do Wall Street, Wyd. Studio Emka: 287-293.

Stachak S. 2013. Podstawy metodologii nauk ekonomicznych. Wyd. Difin: 77-86.

Stanger-Hall K., Lloyd J., Hillis D. 2007. Phylogeny of North American lightning bugs (Coleoptera: Lampyridae). Implications for the evolution of light signals. Molecular Phylogenetics and Evolution. 45(1): 33-49.

Stowe M.K, Tumlinson J.H., Heath R.R. 1987. Chemical mimicry - bolas spiders emit components of moth prey species sex pheromones. Science. 236: 964-967.

Szromnik A. (red.) 2015. Marketing terytorialny. Nowe obszary i narzędzia. Edu-Libri. KrakówLegionowo: 56-71.

Sztompka P. 2010. Socjologia. Analiza społeczeństwa. Wyd. Znak: 506-207.

Tatarkiewicz W. 1978. Historia fillozofii PWN Warszawa: 177-183.

Tobarowicz J. 2016. Rola ekonomii behawioralnej i idei umiaru w ekonomii W: Ekonomia umiaru realna perspektywa?. Nowy paradygmat Grzegorza W. Kołodko. PWN Warszawa: 79-89.

Urich C., Emmel T. 1991. Life histories of neotropical butterflies from Trinidad. Dynastor darius darius (Lepidoptera: Nymphalidae: Brassolinae). Tropical Lepidoptera. 2(2): 145-149.

Vane-Wright R. L. 1980. On the definition of mimicry. Biol. J. Linn. Sco. 13(1): 1-6

Vencl F.V., Carlson A.D. 1997. Proximate mechanisms of sexual selection in the firefly Photinus pyralis (Coleoptera: Lampyridae). J. Insect Behav. 11: 191-207.

Weiner J. 1999: Organizm wśród organizmów, [W:] Życie i ewolucja biosfery. PWN, Warszawa: 329-371.

Wiens D. 1978. Mimicry in plants [W:] Hecht M.K., Steere W.C., Wallace B.(red.) Evolutionary biology. 11, Plenum Press, New York, London: 365-403.

Wilson E.O. 2000. Socjobiologia. Wyd. Zysk i Ska, Poznań: 162-196.

Wilson R. and Angiletta M. 2015. Dishonest signaling during aggressive interactions: theory and empirical evidence. [W:] Duncan J., Irschick M., Briffa J. - Animal Signaling and Function: 205227.

Yeargan K.V. 1994. Biology of bolas spiders. Annu Rev Entomol. 39: 81-99.

\section{Summary}

The aim of the study was to find and evaluate the analogy between the universality of the phenomenon of deception in nature and in economy. In both areas of the analysis, this most often takes a form of mimicry (defensive or aggressive). To create such complex forms of deception among animals, mostly contributed the prevalance of predator-victim model, and using guises or pretending to be something else, was supposed to provide protection against attack or just to facilitate such attack. In the economy one can find attitudes that take the form of mimicry, and thus analogous to the nature, which are also based on pretending to be someone else. This is used by some exploiters, reaping on stereotypes and automatisms of human behaviour. They are most often found in the marketing sphere, taking up very professional and sophisticated forms of attitudes of marketers and represented by them entities. Also there may be found some symmetry and analogies of behaviours in terms of gaining individual benefits at the expense of others. 
Key words: mimicry, nature, deception, economy

Informacja o autorach:

\section{dr Kamila Musial}

Instytut Zootechniki, Państwowy Instytut Badawczy

Zakład Systemów i Środowiska Produkcji

ul. Krakowska 1, 32-083 Balice

e-mail: kamila.musial@izoo.krakow.pl

ORCID: 0000-0002-6713-341X

prof. dr hab. Wiesław Musial

Uniwersytet Rolniczy w Krakowie

Instytut Ekonomiczno-Społeczny

Zakład Ekonomiki i Organizacji Rolnictwa

al. Mickiewicza 21, 31-120 Kraków

e-mail: wieslaw.musial@urk.edu.pl

ORCID: 0000-0002-8213-4859 